\title{
The Relationship Between Being Exposed to Culture Through Social Media and the Willingness to Learn English
}

\author{
Assrar Abdullah ${ }^{1}$, Basma Bukhari ${ }^{1}$ \& Fatimah Almutairi ${ }^{1}$ \\ ${ }^{1}$ English Language Institute, King Abdulaziz University, Jeddah, Saudi Arabia \\ Correspondence: Assrar Abdullah, English Language Institute, King Abdulaziz University, Jeddah, Saudi Arabia.
}

Received: Feburary 14, 2019 Accepted: March 10, 2019 Online Published: March 12, 2019

doi: 10.5539/elt.v12n4p62 URL: https://doi.org/10.5539/elt.v12n4p62

\begin{abstract}
This study is an attempt to investigate the relationship between exposure to a native culture and the learners' willingness to learn the language of the native cultur. A questionnaire with closed-ended items and open-ended questions was used to collect data. Responses to the questionnaire were collected from 54 female students at a public university in Saudi Arabia. In general, the questionnaire results indicated that there is a relationship between exposure to the native culture and the learners' willingness to learn the language. The findings revealed that being exposed to a certain culture makes the learners more willing to learn the language of that culture. Moreover, the findings of the study stressed the importance of adopting social media networking to assist in the process of integrating culture into teaching English as a foreign language. Furthermore, based on the findings of this study, we encourage teachers to allocate as much time as possible to introducing cultural aspects in foreign language classrooms with the aid of social media.
\end{abstract}

Keywords: social media, language teaching and learning, cultural awareness

\section{Introduction}

Human beings have always lived in a world of communication in which different cultures meet in various, easily accessible networking sites. People are in almost continuous interactions with others from different places. Due to the massive technological improvements that we have experienced in the twenty-first century, social media has almost replaced face-to-face communication. It has become an inseparable part of our lives that has provided us with a completely new lifestyle, demands and regulations. Social media involves different kinds of networking sites, such as Snapchat, Instagram, Twitter, Facebook, Tumbler and many more. Each of these social networking sites has its own unique functional features. However, all of them share one common feature, which is enhancing communication among their users. Straubhaar, LaRose, and Davenport (2013) pointed out that our lives currently revolve around several types of media, such as YouTube, Facebook and Twitter.

Since social media has become part of our identity and our experience of life by shaping and defining us and others, its influence is undeniable; this influence does not belong to one culture only, as it combines multiple cultures and audiences with different cultures in a single context, making it easy to affect and be affected by other cultures. Considering how widely social media is used as a medium of communication, it has had a profound impact on the language we use to communicate. Therefore, it is important for us, as EFL teachers, to investigate the impact of social media on learning English as a foreign language.

To do so, the current study attempts to shed some light on the impact of learning the culture of native English speakers through social networking sites on the learners' willingness to learn the language. It attempts to contribute to answering the following questions:

1)- Is there a relationship between the amount of exposure to social media and learning the culture of native speakers of English?

2)- Is there a relationship between knowing the culture of the native speakers of English and the learners' willingness to learn English?

3)- What cultural aspects do Saudi EFL learners learn through social media?

\subsection{Definition and Aspects of Culture}

Before exploring a broad concept such as culture, it is important to have a definition of it. Many definitions have 
been suggested for the term culture in the field of foreign language learning and teaching, in which each definition looks at culture in a different way. It is beyond the scope of the current study to discuss all the possible definitions. However, one comprehensive definition was provided by Hofstede (2011, p. 3), who defined culture as "the collective programming of the mind that distinguishes the members of one group or category of people from others".

We also need to examine the aspects that define the term culture in order to have a better understanding of it. Barro, Byram and Morgan (1993) categorized aspects of culture into seven different types, including "everyday activities, personal and social life, the world around us, education, training and work, the world of communication, the international world, the world of imagination and creativity" (as cited in Arabski \& Wojtaszek, 2011, p. 265). Prodromou (1992) aligned himself with their categorization by recognizing a similar set of aspects of culture. For Prodromou, culture included music, food, education, festivals, media, art, literature and all the cultural factors that constitute a culture's identity (1992). Furthermore, Prodromou (1992) identified cultural identity as the unifying characteristics that are tied to the culture's members. In addition to the aspects mentioned above, Moran and Lu (2001) added practices, which include taboos, and verbal and non-verbal language.

\subsection{Cultural Awareness and Language Learning}

Cultural awareness is an important term because it links culture to language learning. Tomalin and Stempleski (2013, p. 11) defined it as "sensitivity to the impact of culturally induced behavior on language use and communication". For these authors, culture and language were interwoven. Moreover, they argued that language could not be taught without a reflection of the associated culture.

Brown (1994) stressed the importance of enhancing learners' cultural awareness by encouraging them to realize the differences between their own culture and other cultures (as cited in Cakir, 2006). When learners have the ability to establish a clear and distinct realization of their own cultural identity in relation to other cultures; Byram (1994, p. 53) referred to this as "critical cultural awareness" (CCA), and defined (CCA) as "an ability to evaluate critically and on the basis of explicit criteria perspectives, practices and products in one's own and other cultures and countries". He argued that developing the learners' CCA would enable them to communicate successfully in a cross-cultural communication context.

As mentioned above, culture has many aspects, of which language is one. Kramsch (1998, p. 3) associated language with culture according to three different views; with regard to the first, Kramsch stated that, when people use words to express their own thoughts, beliefs, facts and experience, they are using language to express "cultural reality". The second view is that, when people use language to communicate with each other, they employ different methods of communication. Examples include face-to-face, telephone calls, and texts messages; thus language embodies cultural reality. With regard to the last view, Kramsch $(1998$, p. 3) identified language as "a system of signs that is seen as having itself a cultural value"; therefore, when people use language to represent themselves, language symbolizes cultural reality. In these three views, Kramsch (1998) shed light on how different uses and purposes of language eventually shape a culture.

Learning a foreign language within an educational classroom setting should not be limited only to teaching the linguistic components of language while completely excluding the cultural aspects that might affect the process of learning. In this vein, previous studies by Baranovskaja and Skorupa (2011) and Hyde (1998) found that cultural aspects should not be separated from the teaching and learning of a foreign language. Baranovskaja and Skorupa (2011), for example, assumed that a successful learning process for a foreign language depended mainly on being exposed to its cultural elements. Hyde (1998), in her research "A Look at Culture in Relation to Various Models of English Language Teaching", questioned whether teaching a language without any reflection of its target culture was sufficient to ensure foreign language proficiency. She argued that teaching cultural aspects of a foreign language was essential in order to master proficiency. She concluded that teaching a foreign language should consider including its target culture. In summary, for learners to become proficient language speakers, language must be taught with an emphasis on its cultural aspects (Baranovskaja \& Skorupa, 2011; Hyde, 1998). Apart from mastering linguistic proficiency, inter-cultural communication success relies on the cultural aspects of a language which are required to achieve successful Inter-Cultural Communication Competence (ICC) (Baranovskaja \& Skorupa, 2011; Hyde, 1998). In this regard, Young and Sachdev (2011) identified ICC as the ability to communicate successfully and effectively with people from different cultures.

Nevertheless, other researchers, such as Moran and Lu (2001), have advocated separating the teaching of language and the teaching of culture. They pointed out that a learner can only use the language to learn about the culture after having mastered the target language. Furthermore, in his article " Teaching Culture in the Foreign 
Language Classroom", Brooks (1968) stated that, before teaching culture to EFL students, it is important for the teacher to define and describe what culture is in terms that will make sense to them. Noting that teaching culture to EFL students is not an easy task, Brooks (1968) also suggested that the teacher must be sufficiently qualified to teach culture. This can be accomplished by teacher trained and having teachers attend training workshops, as well as teachers taking some specialized college courses, doing research projects, attending seminars and conferences that are supported by professional groups, and even taking standards tests. After having accomplished these tasks, Brooks (1968) stated that a teacher would be able to teach culture that makes sense to his/her students effectively.

\subsection{Learning Culture Through Social Media}

According to Baruah $(2012$, p. 2), the term social media refers to "the use of web-based and mobile technologies to turn communication into interactive dialogue". Socializing with others is part of human nature. This is why social media is widely used, especially among teenagers. Moreover, teenagers tend to have a need to follow role models, and wish to imitate and sound like them. This, according to Miller (2008), helps to increase their sense of engagement with society.

Social media serves to increase the distance of the concept of 'the social' from a focus on human groups to something that takes our increasing engagement with a variety of objects, tools, and technologies (such as mobile phones, computers, blogs, and social networking profiles) into account, which not only allow us, but encourages us, to engage with others via these devices. Human relationships have become increasingly dependent on, and even displaced by, objects. Thus, when human beings are engaged in intensive social communication networking, they are most likely to influence each other.

Grossberg (2006) argued that media making evolved in two main stages. The first was is the 'television generation' during the 1960s and 1970s. During this stage, the media was influenced by the cultural form of mainstream media, movie scenes, actors, directors, and what the people watched, read, and learned from television. The new stage, according to the author, is the Internet and mass-media generation including social media. Being exposed to such a huge expanse of media has had a massive effect, both consciously and unconsciously, on "“what' people think and 'how' they think about themselves and others" (Tisdell. 2008).

The relationship between media and culture has been studied extensively. In his book, Grossberg (2006) discussed the relationship of culture, media, and education. He pointed out that this relationship became part of the schema of a movement that defined the direction of society, which is why it is difficult to separate the study of culture from the study of mass media. Moreover, Moran and Lu (2001) stated that teaching culture to EFL students effectively could be done via mass media.

\section{Method}

\subsection{Participants}

The current study surveyed fifty-four female Saudi EFL learners via snowball sampling, whereby each student shared the questionnaire with others. All variables other than the ones we were investigating were controlled to ensure the internal validity of the research (Mackey \& Gass, 2005). The participants were all Saudis and had the same L1. All of them were female intermediate learners at the English Language Institute at King Abdulaziz University.

\subsection{Research Method and Procedure}

A questionnaire (see the appendix) was designed using Google forms. It was piloted using 20 participants before being distributed on-line. The questionnaire was developed by the researchers.

The questionnaire was divided into three sections:

1) A Likert scale,

2) Items that allowed the participants to choose one or more response

3) An open-ended question.

In the first section, namely the Likert scale, each answer was assigned a score ranging from 5 for strongly agree to 1 for strongly disagree. The overall score of the items in the questionnaire was 65 . If the score was 65 , this meant that social media had helped the participant to learn about the cultures of native English speakers and that she agreed that this had a positive effect on her willingness to learn English. On the other hand, if the score was low, this meant that social media did not help the respondent to learn either the culture or the language. Four items were included in the second section. The first was used to measure the amount of time Saudi EFL students 
spent on social media, while the other three items were used to measure the cultural aspects that had been learned via social media. Finally, in the third section of the questionnaire, an open-ended question was used to measure the effect of being exposed to culture through social media on the learners' willingness to learn English.

\subsection{Analysis of Method}

To answer the research questions, all data were analyzed quantitatively using SPSS Version 22 except the open-ended question, which was analyzed qualitatively using NVivo Version 11. The relationship among the variables was also measured using SPSS. Microsoft Word was used to draw tables, graphs, and charts.

\section{Results}

As mentioned previously, the questionnaire was divided into three sections. The first section was a Likert scale $($ Cronbach's alpha $=0.830)$ that consisted of 13 items.

Table 1. Learners' scores on the questionnaire

\begin{tabular}{lll}
\hline Condition & $M(S D)$ & $\mathrm{N}$ \\
\hline The effect of social media on learning about other cultures & $24.352(3.6609)$ & 54 \\
The effect of learning about other cultures on the willingness to learn English & $27.889(4.4623)$ & 54 \\
\hline
\end{tabular}

As explained earlier, each response to the questionnaire was assigned a score that ranged from 5 for strongly agree to 1 for strongly disagree. The higher the score, the stronger the impact of social media on learning about the cultures of native English speakers. The scores were calculated by summing the scores for all the items. A descriptive analysis was then conducted to measure the mean and the standard deviation of the scores. These values can be seen in Table 1. From the mean value, it can be seen that the scores were high, which means that social media did play a strong role in learning about other cultures, and that this had an effect on the learners' willingness to learn a language.

Table 2. Correlation between Exposure to Social Media and Learning about the Cultures of Native Speakers of English

\begin{tabular}{lll}
\hline & & $\begin{array}{l}\text { Learners' scores for the items that measured learning } \\
\text { about the culture }\end{array}$ \\
\hline $\begin{array}{l}\text { Amount of time exposed to } \\
\text { media: }\end{array}$ & $\begin{array}{l}\text { Pearson } \\
\text { Correlation } \\
\text { Sig. (2-tailed) }\end{array}$ & .319 \\
& $\mathrm{~N}$ & 54 \\
\hline
\end{tabular}

In order to answer the first research question concerning the relationship between the time spent on social media and the learners' cultural awareness, we first asked the participants about the amount of time they spent on social media. The results show that they spent between one and six hours per day $(\mathrm{M}=2.5)$. A Pearson product-moment correlation was run to determine the relationship between the time spent and learning about the culture. Table 2 shows the results of the correlation. As the results show, there was a strong relationship between the amount of exposure to media and learning about another culture.

Table 3. Correlation between cultural awareness and willingness to learn the language

\begin{tabular}{lll}
\hline & Willingness to learn the language \\
\hline Learning about the culture: & Pearson Correlation & .392 \\
& Sig. (2-tailed) & .01 \\
$\mathrm{~N}$ & 54 \\
\hline
\end{tabular}

To answer the second research question regarding the relationship between learning about the cultures of native 
English speakers and the willingness to learn English, a Pearson product correlation was run. Table 3 shows the results of the correlation.

Moreover, the participants' responses to the open-ended question emphasized the importance of learning about the culture on order to be interested in learning the language. The learners' responses were analyzed using NVivo. The main themes that emerged from the analysis were Learning Language in Context and the Willingness to Learn the Language. Regarding the first theme, one of the participants stated that "it is important to learn the language in its real context, which includes culture, to be able to understand it". Another participant emphasized the importance of learning about the culture to understand vocabulary in particular: "[I]t is sometimes hard to understand some idioms or proverbs without understanding the culture of the speaker". Concerning the second theme, a participant stated: "Knowing the American and British culture through media made me more interested to learn English"

As the results show, it is extremely important for language learners to learn about the culture in order to be able to learn the language. This corresponds with what was found by several researchers (Baranovskaja \& Skorupa, 2011; Hyde, 1998; Chunhong \& Griffiths, 2011; Hismanoglu, 2011), who asserted that, in order to be a successful language learner, one must be exposed to the foreign culture as part of the learning process. However, this finding contradicts what was suggested by Moran (2001), who was of the opinion that teaching culture did not help in the process of language learning.

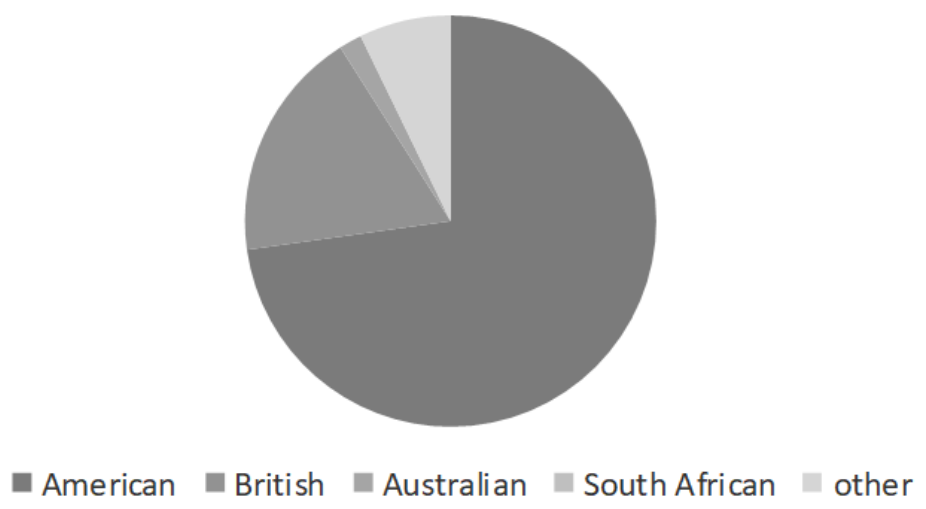

Figure 1. About which culture do you know the most because of media?

To answer the last research question concerning the cultural aspects that Saudi EFL learners acquired through social media, we first asked the participants to specify the culture about which they knew the most. Fgure 1 shows that, due to the frequent exposure to American media channels, learners knew more about the American culture than they did about any other culture.

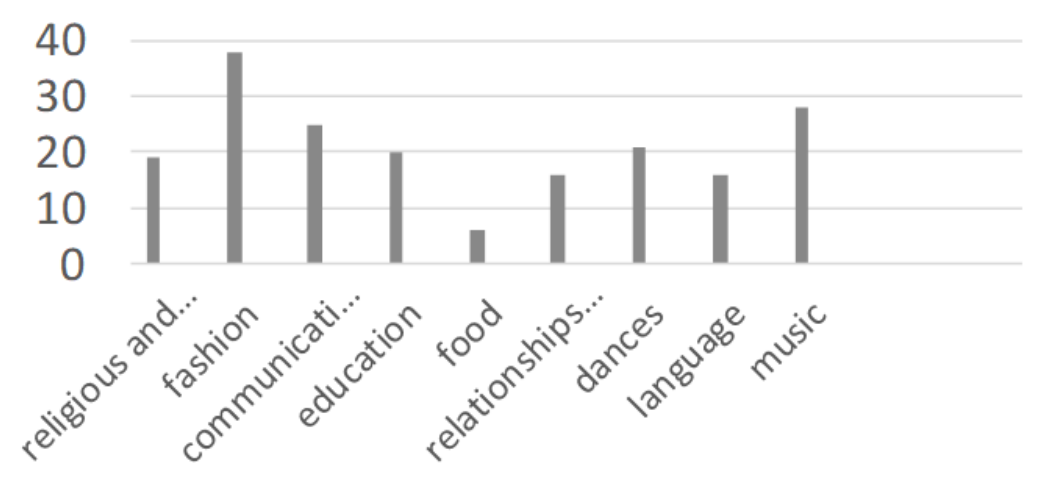

Figure 2. What cultural aspects did you learn about through media?

The participants were also asked to specify the cultural aspects about which they had learned via social media. 
These aspects were adapted from Prodromou (1992) and from Moran (2001). Figure 2 shows the frequency of their responses. Their responses show that they knew more about fashion and music than they did about any other aspects. This can be justified by the characteristics of the sample, namely their age and gender, since they were all young female learners.

\section{Conclusion and Limitations}

This study attempted to investigate the relationship between exposure to the native culture and the learners' willingness to learn the language. The main finding was that being exposed to a certain culture made the learners more willing to learn the language of that culture.

There are several limitations in the current study. The first is related to the sample; all the participants in this study were female. To obtain more generalizable findings, the same study should be conducted from male EFL Saudi learners' perspectives. The second limitation is related to the instrument. Questionnaires cannot be used alone to investigate as broad a concept as culture (Mackey \& Gass, 2005). The data should be collected using different instruments to obtain results that are more accurate. However, due to time constraints, it was difficult to consider employing a qualitative paradigm in this research. Given this fact, it is hoped that future researchers will investigate this topic using different scales to obtain a deeper understanding thereof.

Despite the limitations discussed above, the findings of this study indicated the importance of adopting social media networking to assist in the process of integrating culture into teaching English as a foreign language. Moreover, based on the findings of this study, we encourage teachers to allocate as much time as possible to introducing cultural aspects into foreign language classrooms with the help of social media.

\section{References}

Arasbski, J., \& Wojtaszek, A. (Eds). (2011). Aspects of culture in second language acquisition and foreign language learning. New York: Springer. https://doi.org/10.1007/978-3-642-20201-8

Baruah, T. D. (2012). Effectiveness of Social Media as a tool of communication and its potential for technology enabled connections: A micro-level study. International Journal of Scientific and Research Publications, 2(5), 1-10.

Brooks, N. (1968). Teaching culture in the foreign language classroom. Foreign Language Annals, 1(3), 204-217. https://doi.org/10.1111/j.1944-9720.1968.tb00135.x

Byram, M., \& Zararte, G. (1994). Definitions, objectives, and assessment of socio-cultural competence. Strasbourg, France: Council of Europe.

Cakir, I. (2006). Developing cultural awareness in foreign language teaching. Turkish Online Journal of Distance Education (TOJDE), 7(3), 154-161. Retrieved from http://dergipark.gov.tr/tojde/issue/16925/176666

Grossberg, L., Ellen, W., \& Charles, W. (1998). Mediamaking: Mass Media in a Popular Culture. Thousand Oaks, CA: SAGE.

Hofstede, G. (2011). Dimensionalizing cultures: The Hofstede model in context. Online Readings in Psychology

and Culture, 2(1), 8. https://doi.org/10.9707/2307-0919.1014

Hyde, M. (1998). A Look at Culture in Relation to Various Models of English Language Teaching. In R. Cherrington, \& L. Davcheva (Eds.). Teaching Towards Intercultural Competence. Bulgaria: The British Council.

Kramsch, C. (1998). Language and culture. Oxford: Oxford University Press.

Miller, V. (2008). New media, networking and phatic culture. Convergence, 14(4), 387-400. https://doi.org/10.1177/1354856508094659

Moran, P. R., \& Lu, Z. (2001). Teaching culture: Perspectives in practice. Boston, MA: Heinle \& Heinle.

Prodromou, L. (1992). What culture? Which culture? Cross-cultural factors in language learning. ELT Journal, 46(1), 39-50. https://doi.org/10.1093/elt/46.1.39

Straubhaar, J., LaRose, R., \& Davenport, L. (2011). Media Now: Understanding Media, Culture, and Technology. Belmont, CA: Wadsworth.

Tisdell, E. J. (2008). Critical media literacy and transformative learning: Drawing on pop culture and entertainment media in teaching for diversity in adult higher education. Journal of Transformative Education, 6(1), 48-67. https://doi.org/10.1177/1541344608318970 
Tomalin, B., \& Stempleski, S. (2013). Cultural Awareness - Resource Books for Teachers. Oxford: Oxford University Press.

Young, T. J., \& Sachdev, I. (2011). Intercultural communicative competence: Exploring English language teachers' beliefs and practices. Language Awareness, 20(2), 81-98. https://doi.org/10.1080/09658416.2010. 540328

\section{Appendix}

\section{تأثير وسائل الاعلام الأجنبية على زيادة وعي الطالبات بالثقافات الأخرى}

يسرنا مساهمتك معنا في تعبئة الاستبيان التالي علماً بأن البحث يتعلق بتأثير وسائل الاعلام الأجنبية المختلفة برفع وعي الطالبات تجاه الثقافات الأخرى. الاسم:

$$
\begin{aligned}
& \text { المستوى الدراسي في مادة اللغة الإنجليزية: } \\
& \text { م الأول } \\
& \text { O الثاني } \\
& \text { م الثالث }
\end{aligned}
$$

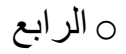

$$
\begin{aligned}
& \text { أو افق على مشاركتي بالبحث: } \\
& \text { O نعم } \\
& \text { yo }
\end{aligned}
$$

\section{أي نوع من الإعلاد؟}

$$
\text { ○ } 0
$$




$$
\begin{aligned}
& \text { 2. أكثر وسيلة إعلام اتابعها باللغة الإنجليزية هي: } \\
& \text { م التلفزيون } \\
& \text { O } \\
& \text { O م وسائل التواصل الإجتماعي }
\end{aligned}
$$

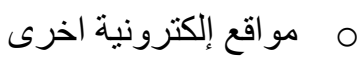

$$
\begin{aligned}
& \text { م مرائد ومجلات } \\
& \text { O اخرى (الرجاء ذكرها) }
\end{aligned}
$$

$$
\text { 3 } 0
$$

\section{ثقافةت؟}

4. بعد متابعتي لوسائل الإعلام الأجنبية باللغة الإنجليزية تعلمت ولو قليلاً عن الثقافة (يمكن اختيار أكثر من إجابة): O O O O م الجنوب أفريقية O اخرى (الرجاء ذكر ها):

5. أعرف ثقافة الدولة التالية أكثر من غير ها بفضل متابعة وسائل الإعلام الأجنبية باللغة الإنجليزية: O الأمريكية O O O م الجنوب أفريقية م اخرى (الرجاء ذكرها):

$$
\text { 6. } 0
$$




$$
\begin{aligned}
& \text { o الطعام و ادابه في الثقافات الاخرى }
\end{aligned}
$$

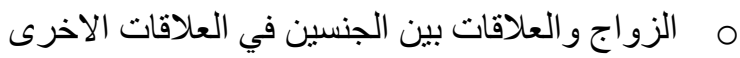

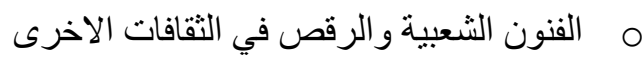

$$
\begin{aligned}
& \text { o اللغة في الثقافات الاخرى } \\
& \text { O الموسيقى في الثقافات الاخرى } \\
& \text { o الجديد و الثائع في الثقافات الاخرى } \\
& \text { o ت ماريخ الثقافات الاخرى } \\
& \text { م غير ها: }
\end{aligned}
$$

\begin{tabular}{|c|c|c|c|c|c|}
\hline لا أو افق بشدة & لا أو افق & محايد & أو افق & أو افق بشدة & \\
\hline & & & & & 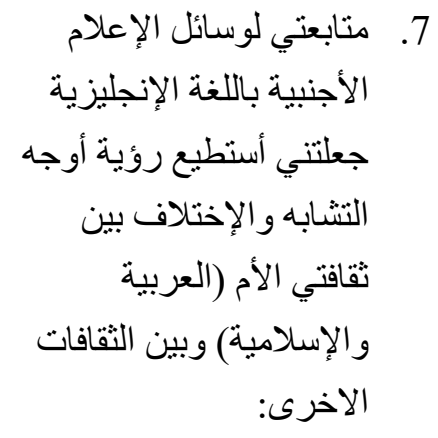 \\
\hline & & & & & 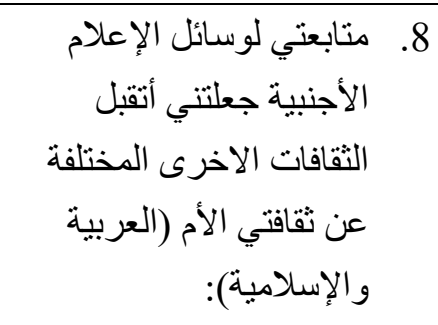 \\
\hline & & & & & 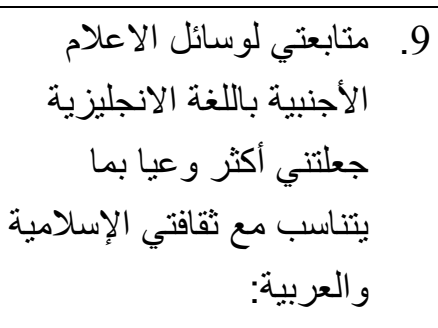 \\
\hline & & & & & 10. متابعتي لوسائل الاعلام \\
\hline
\end{tabular}

\section{كيف ساعدتك وسائل الإعلام على فهر وتقبل الثقافات الاخرى؟ الرجاء الاختيار من الخيارات التالية.}




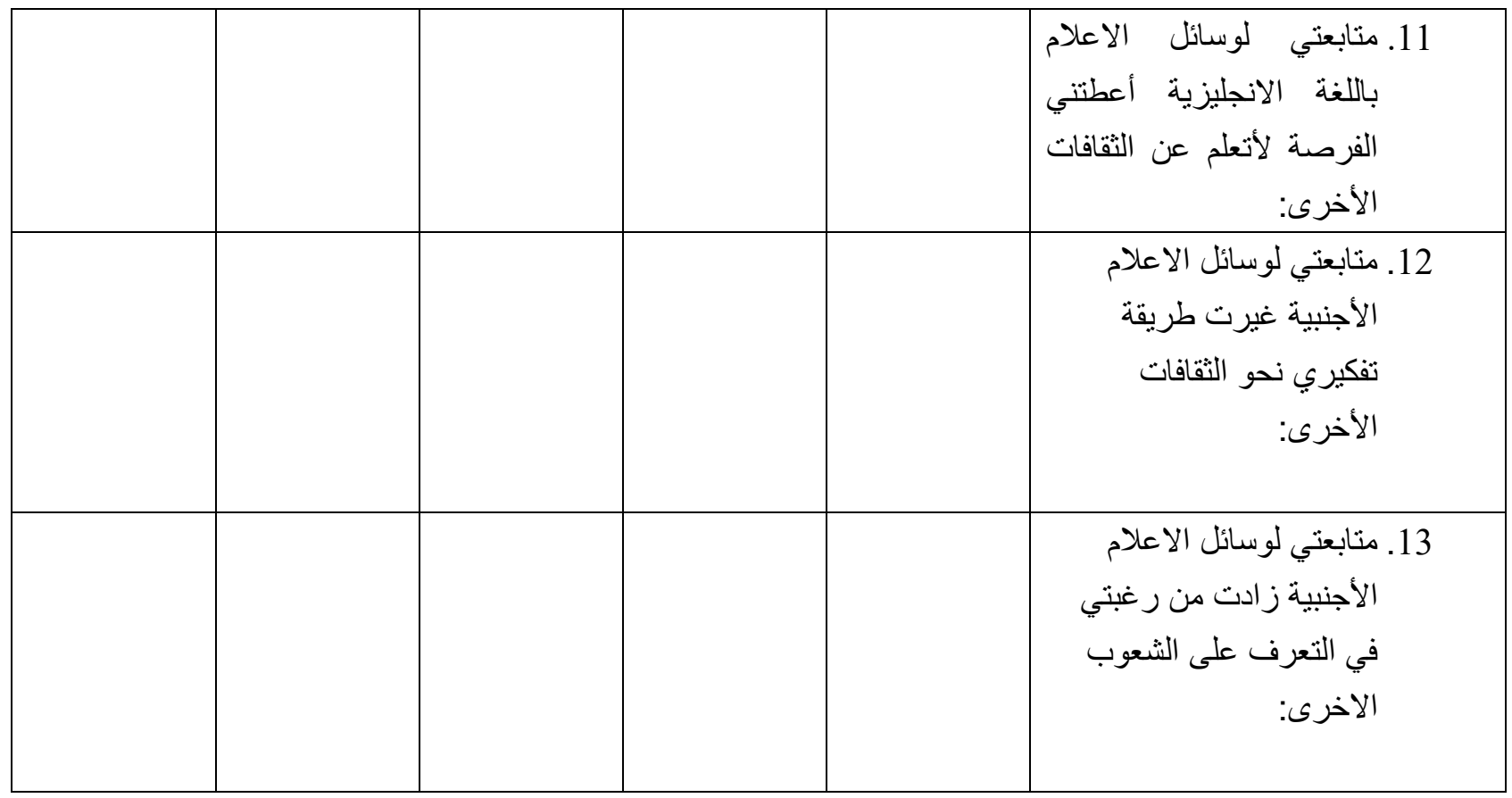

كيف يساعدك فهم الثقافات الأخرى فى تعلم اللغات؟

\begin{tabular}{|c|c|c|c|c|c|}
\hline لا لا أوافق بشدة & لا لأوافق & محايد & أو افق & أو افق بشدة & \\
\hline & & & & & 14. عند متابعة وسائل الاعنلام \\
\hline & & & & & 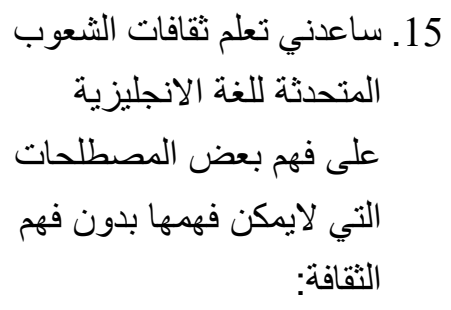 \\
\hline & & & & & 16ـ تعلم ثقافة أي شعب مهم لتعلم \\
\hline & & & & & 17. تعلم ثقافة شعب أخر يجعلني \\
\hline & & & & & 18. أحيانا لايمكن فهم بعض \\
\hline
\end{tabular}




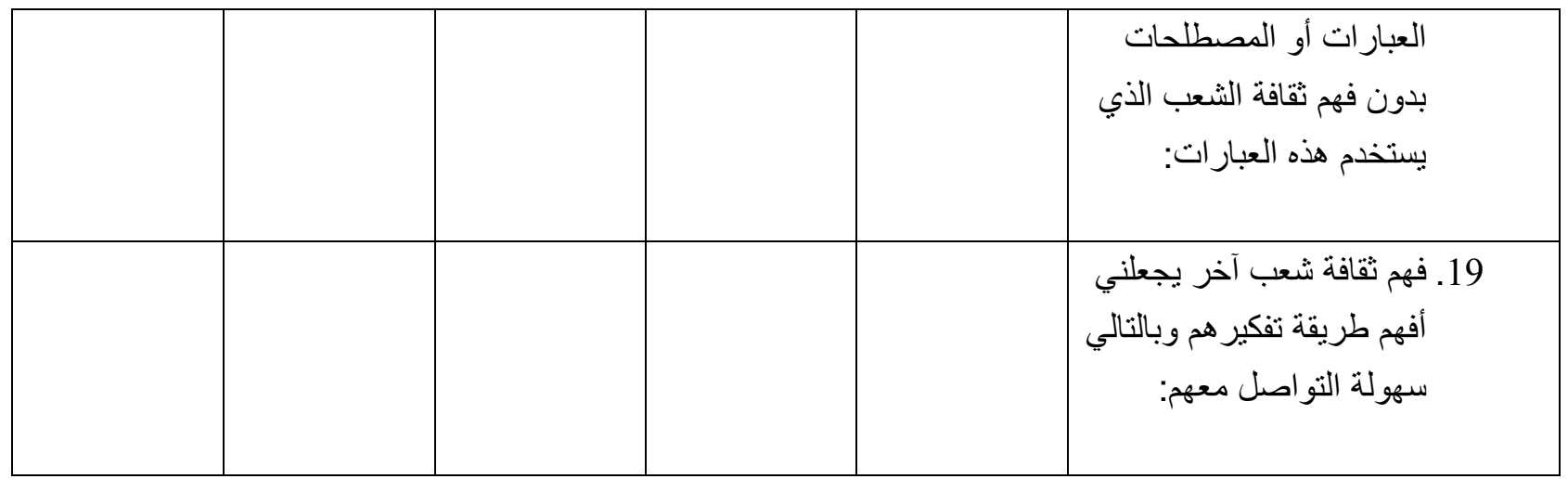

20. كيف ساعدك فهم ثقافات الثعوب الناطقة باللغة الإنجليزية على تعلم اللغة الانجليزية (الرجاء اعطاء أمثلة):

شكر الع

\section{Copyrights}

Copyright for this article is retained by the author(s), with first publication rights granted to the journal.

This is an open-access article distributed under the terms and conditions of the Creative Commons Attribution license (http://creativecommons.org/licenses/by/4.0/). 